International Journal of Instruction e-ISSN: 1308-1470 • www.e-iji.net

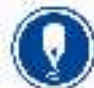

Article submission code: 20200331035454
Received: 31/03/2020

Revision: $24 / 11 / 2020$
July $2021 \bullet$ Vol.14, No.3

p-ISSN: 1694-609X

pp. 59-72

Accepted: 19/12/2020

OnlineFirst: 08/04/2021

\title{
Assessing Psychosocial Skills and Negative Emotional States of Elementary School Students in Yogyakarta Area
}

\section{Soni Nopembri}

Faculty of Sport Sciences, Universitas Negeri Yogyakarta, Indonesia, soni_nopembri@uny.ac.id

\section{Yoshio Sugiyama}

Faculty of Human-environment Studies, Kyushu University, Japan, sugiyama@ihs.kyushu-u.ac.jp

Students in Yogyakarta area require skills to meet the psychological and social challenges of high-risk natural disaster and daily life. Therefore, it requires study to explore the various students' psychosocial skills based on teachers' perspective and negative emotional states. Both qualitative and quantitative analysis were used to examine the data. The study conducted semi-structured interviews on nine physical education teachers from elementary schools in Yogyakarta. Three teachers were from the schools located in Disaster Area of volcano, two teachers were from schools in Urban Area, and four teachers were from schools located in Suburban Area. A Depression Anxiety Stress Scale (DASS) 42 survey was also used to explore the negative emotional state of the 745 elementary school students from fourth to sixth grades in three different areas. The Physical Education (PE) teacher perceived that students' essential psychosocial skills are sufficient, but they still require skills in the following areas: stress coping, communication, social awareness, and problem solving. The children who lived in the disaster area had a lower negative emotional state than those who lived in the urban and suburban areas. The future program should involve variety of activities to decrease students' negative emotional state and develop their psychosocial skills harmoniously.

Keywords: psychosocial skills, negative emotional states, teacher, student, elementary school

\section{INTRODUCTION}

Yogyakarta is a Special Region in Indonesia. It is located near the southern coast of Java Island. It has an area of $3,185.80 \mathrm{~km}^{2}$ (Government of Yogyakarta Special Region, 2010). Several natural disasters have occurred in Yogyakarta, for example, a 6.3 magnitude earthquake have killed more than 5,000 people, and injured about 36,000 on May 27, 2006 (Nichols, 2008). Another disaster was caused by the Indonesian most active volcano located in Yogyakarta area, Merapi, killing 196 and injuring 258 persons,

Citation: Nopembri, S., \& Sugiyama, Y. (2021). Assessing Psychosocial Skills and Negative Emotional States of Elementary School Students in Yogyakarta Area. International Journal of Instruction, 14(3), 59-72. https://doi.org/10.29333/iji.2021.1434a 
destroying 3,245 houses, and temporarily displacing approximately 410,338 people in the last eruption on October-November 2010 (Sagala et al., 2012). For those reasons, the Yogyakarta area has a high risk for natural disasters.

Natural disasters such as earthquakes and volcano eruption have an impact on the human victims psychologically, especially children. Disaster has always resulted in a display of symptoms of trauma and secondary traumatization on the children (Kilic, Ozguven, and Sayil, 2003). Particularly, children are vulnerable to disaster trauma manifested in psychological and behavioral complex (Kar, 2009). Research found that stress symptoms in children appeared after the earthquake immediately (Mondal et al., 2013). Children are most likely exposed to injuries, dying, or dead when a disaster happened (Rønholt, Karsberg, and Elklit, 2013). Yonekura, Ueno, and Iwanaka (2013) recommended that children who have lost everything in disaster need social support and mental health in long term. Comprehensive intervention and psychological is needed by children after the disaster (Uemoto et al., 2012).

Schools are the ideal place to implement post-disaster interventions (Wolmer, Laor, Dedeoglu, Siev, \& Yazgan, 2005). Schools are well placed to promote health and physical activity behaviors because of the amount of time students spend in this environment and the elements of the school curriculum that are adaptable to include such content (Jenkinson \& Benson, 2010). The school environment is a very influential social determinant of physical activity and constant interaction with peers can greatly affect choices, including participation in physical education and physical activity (Jenkinson \& Benson, 2010). Physical education may have an important educational contribution to students' personal development (Hassandra, Goudas, \& Chroni, 2003). It provides opportunities for enjoyment, for learning new motor skills and for cooperating with others (Hassandra, Goudas, \& Chroni, 2003). Participation in physical exercises and sports requires strong attitudes toward physical activities (Al-Rawahi \& Al-Yarabi, 2013).

Teacher is also an important element in schools in relation to psychological and social developments. Teachers can play an essential role in helping students learn and apply a moral-reasoning process to serve as role models for telling the truth, respecting others, accepting and fulfilling responsibilities, playing fair, earning and returning trust, and living a moral life (Lumpkin, 2008). In the disaster relief, teachers may become efficient clinical mediators, helping to cope with the dearth of child professionals who are trained (Wolmer, Laor, Dedeoglu, Siev, \& Yazgan, 2005). Teaching behaviors of the teacher may support or thwart students' innate psychological needs for autonomy, competence, and relatedness were explored (Taylor, Ntoumanis, \& Smith, 2009).

Physical education (PE) teachers provide an important role in the psychosocial development of the students. PE teachers can help students meet these standards by stressing the importance of character and moral virtues (Lumpkin, 2008). Physical education teachers can evaluate character education as a process of forming individual habits in society (Tutkun, Görgüt, and Erdemir, 2017; Görgüt and Tutkun, 2018). PE teachers not only can teach about sports but can also change student personalities, promote friendship between students and teachers and emotional resonance (Fan, 2015). 
Greater awareness of teachers' embodied experiences, in particular their emotional and behavioral reactions to aspects of the teaching context will help to inform schools and educational bodies on how to aid PE teachers in delivering better quality teaching to all students (Taylor, Ntoumanis, \& Smith, 2009).

Based on the relation of schools, teachers, and students, it is very important to investigate the necessary psychosocial skills for students in Yogyakarta area. This also supported by the Erikson's Psychosocial Development theory, which stated that the children 6-12 age have a unique characteristic on psychosocial skills (Chung, 2018). The research is necessary to investigate of the role of PE teachers as an important person in the psychosocial development of students' efforts. In particular, the PE teachers knew various psychosocial skills needed by students. For this reason, the study aim to explore various psychosocial skills for fourth- to sixth-grade elementary school children from the PE teachers' perspective, and to investigate children's negative emotional states in the urban, suburban, and disaster area of Yogyakarta, Indonesia. Therefore, the research questions are (1) what are the psychosocial skills of elementary school students and (2) what is the negative emotional state of grades 4th-6th elementary school students.

\section{METHOD}

Mixed methods research designs were implemented in this study. We use the qualitative and quantitative data resources to validate the findings. A qualitative data resource was by individual semi-structured interviews with the nine PE teachers to gain an in-depth information of PE and sports teachers' perceptions about children's psychosocial skills in $\mathrm{PE}$ and sports classes and their daily school activities. A quantitative data resources was used to explore the negative emotional state of the 745 elementary school children from fourth to sixth grades. The procedure of this study is shown in Table 1.

Table 1

Research designs

\begin{tabular}{ll}
\hline Qualitative Process & Quantitative Process \\
\hline $\begin{array}{l}\text { Nine (9) PE teachers with 4 to 29 years } \\
\text { teaching experience }\end{array}$ & $\begin{array}{l}\text { A total 745 elementary students from fourth } \\
\text { to sixth-grades. }\end{array}$ \\
\hline Semi-structured interview & $\begin{array}{l}\text { Administered the Depression, Anxiety, and } \\
\text { Stress Scales (DASS 42) }\end{array}$ \\
\hline $\begin{array}{l}\text { Qualitative analysis through data display, } \\
\text { reduction, and verification/conclusion }\end{array}$ & $\begin{array}{l}\text { One-way ANOVA to compare depression, } \\
\text { anxiety, and stress state between area }\end{array}$ \\
\hline
\end{tabular}




\section{Participants}

Table 2

The Characteristics of PE teachers

\begin{tabular}{llll}
\hline Initial Teacher & Gender & Teaching Experience (Years) & Area \\
\hline T1 & F & 4 & Disaster \\
\hline T2 & M & 19 & Disaster \\
\hline T3 & M & 4 & Disaster \\
\hline T4 & M & 17 & Urban \\
\hline T5 & F & 24 & Urban \\
\hline T6 & M & 29 & Suburban \\
\hline T7 & M & 16 & Suburban \\
\hline T8 & M & 9 & Suburban \\
\hline T9 & M & 9 & Suburban \\
\hline
\end{tabular}

The nine (two females and seven males) PE and sports teachers at the elementary schools in Yogyakarta consisted of three teachers in a disaster area, two in the urban area, and four in a suburban area. The teaching experiences of the PE and sports teachers are ranging from 4 to 29 years in the school. The brief characteristics of these participants have shown in Table 2.

Table 3

The characteristics of the students

\begin{tabular}{lllllllll}
\hline \multirow{2}{*}{ Area } & \multirow{2}{*}{ Schools } & \multicolumn{2}{l}{ Gender } & Age & \multicolumn{5}{c}{ Grade } \\
\cline { 2 - 9 } & & $\mathrm{F}$ & $\mathrm{M}$ & Mean & SD & $4^{\text {th }}$ & $5^{\text {th }}$ & $6^{\text {th }}$ \\
\hline Disaster & 3 & 67 & 91 & 10.3 & 1.08 & 52 & 50 & 56 \\
\hline Urban & 2 & 92 & 94 & 10.5 & 1.58 & 59 & 58 & 69 \\
\hline Suburban & 4 & 204 & 197 & 10.6 & 1.13 & 138 & 123 & 140 \\
\hline
\end{tabular}

Note: $\mathrm{F}=$ Female, $\mathrm{M}=$ Male, $\mathrm{SD}=$ Standard Deviation.

A total 745 students of fourth to sixth-graders from three elementary schools located in a disaster area (near Merapi Volcano), two elementary schools located in the urban area (Yogyakarta city), and four elementary schools located in the suburban area (Sleman district) were involved in this study. The characteristics of the children have shown in Table 3.

\section{Data Collection}

\section{Teacher's Interviews Instrument}

The special interview guide developed for this study was based on the factors of research to be known. The selected questions from the interview guide were shown in Table 4. The interviews were carried out in the teacher's room, classroom, or field at the end of the PE and sports lesson. 
Table 4

Interview guide for teachers

\begin{tabular}{ll}
\hline No & Question \\
\hline 1 & How long have you taught in school? \\
\hline 2 & How many children of the $4^{\text {th }}-6^{\text {th }}$ grade in this school? \\
\hline 3 & How are the psychosocial skills characteristics of the children $\left(4^{\text {th }}-6^{\text {th }}\right.$ grade $)$ in general? \\
\hline 5 & $\begin{array}{l}\text { Specifically, what kind of children's psychosocial skills aspects have been developed, such as } \\
\text { stress coping, communication, social awareness, and problem-solving skills? }\end{array}$ \\
\hline 6 & $\begin{array}{l}\text { In your opinion, what children's psychosocial skills elements are needed to develop in their school } \\
\text { daily activities and community? }\end{array}$ \\
\hline 7 & How did you and the school develop children's psychosocial skills? \\
\hline 8 & Have you or the school done children's psychosocial skills assessment/measurement? \\
\hline 9 & $\begin{array}{l}\text { How did you saw the relationship between teacher-student, student-student, and parent-school, } \\
\text { especially in terms psychosocial skills development? }\end{array}$ \\
\hline
\end{tabular}

\section{Teacher's Interviews Procedures}

In-depth semi-structured interviews were conducted for one hour with each teacher to enhance data integrity without losing the opportunity to follow up with questions or to dig deeper into the responses. Therefore, to establish triangulation method, the in-depth semi-structured interview was combined with conversational and structured question interviewing to support the trustworthiness of the data. A semi-structured interview format provided the chance to delve deeper into the participant's responses and ask follow-up questions that lead to a richer and more compelling data (Finn \& McInnis, 2014). Therefore, the teachers answered open questions regarding their perspective on children's psychosocial skills during PE and sports lesson and daily school activities.

\section{Negative Emotional States Instrument}

The negative emotional state of children was measured by the Depression, Anxiety, and Stress Scales-DASS 42 (Lovibond \& Lovibond, 1995). The 42-item questionnaire consists of three self-report scales. Each scale contained 14 items and divided into subscales of 2-5 items with similar content. Dementia, despair, devaluation of life, selfhumiliation, and lack of interest/involvement, anhedonia, and inertia were assessed on the depression scale. The anxiety scale has indicators of autonomic arousal, musculoskeletal effects, situational anxiety, and subjective experience of anxious affect. A chronic non-specific arousal scale assessed sensitivity to stress.

\section{Table 5}

DASS symptom severity ratings (Lovibond \& Lovibond, 1995)

\begin{tabular}{llll}
\hline & Depression & Anxiety & Stress \\
\hline Normal & $0-9$ & $0-7$ & $0-14$ \\
\hline Mild & $10-13$ & $8-9$ & $15-18$ \\
\hline Moderate & $14-20$ & $10-14$ & $19-25$ \\
\hline Severe & $21-27$ & $15-19$ & $26-33$ \\
\hline Extremely Severe & $28+$ & $20+$ & $34+$
\end{tabular}

\section{Negative Emotional States Data Collection Procedures}

Respondents were asked to use a 4-point severity scale to rate the extent to which they have experienced each symptom over the past week. Table 5 shows the severity-rating 
index of DASS. The Indonesian format DASS 42 was used to analyze the validity and reliability for children in our sample. The internal validity $(\mathrm{p}<0.01)$ and a reliability test of Cronbach's alpha (0.904) verified that the DASS 42 was suitable for our sample.

\section{Data Analysis}

The qualitative analysis through three concurrent flows of activity — data reduction, data display, and conclusion drawing/verification (Miles \& Huberman, 1984) - was used to examine the interview results of teachers. One-way analysis of variance (ANOVA) was used to discuss the differences of children's negative emotional state between disaster, urban, and suburban areas in the study.

\section{FINDINGS}

\section{Students' Psychosocial Skills}

The analyses focused on stress coping, communication, social awareness/empathy, and problem-solving skills of children in fourth to sixth grades. Psychosocial skills have many aspects; therefore, the analyses of the research findings were designed to explore the data in more specific detail. Various psychosocial characteristics were identified based on interviews with PE and sports teachers.

The PE and sports teachers believed that the children have not had adequate skills to cope with stress. They frequently saw the children express their feelings of stress through negative behaviors. "The children still tend to be naughty, irritable, and lazy about their learning" (T2/disaster). "The children's visible symptoms of stress include being quiet, being angry, having a "do not care" attitude, or showing lack of concern" (TL/urban). "The children's skills for coping with stress are not too visible" (T6/suburban).

In particular, the teachers felt that the children in the disaster area continued to have deep fears associated with various characteristics of the disaster, such as a hearing a roar, although there were no obvious signs of an impending volcanic eruption. They had not been able to overcome their fears that resulted in their stress condition. "There are still effects of the trauma on the child after the disaster" (T1/disaster). "The children have been afraid of thunder after the disaster, so the development of their social skills has been quite difficult" (T3/disaster). "Children in the catastrophe area still have traumatic stress because of the disaster" (T2/disaster).

The PE and sports teachers also noticed that the children needed to improve their skills for coping with stress, mainly with the help of others. "The children need to develop their skills for coping with stress through sports games" (T3/disaster). "The children's abilities to cope with stress have to be improved" (T5/urban). "Capacity to cope with stress needs to be developed in the children" (T9/suburban).

The PE and sports teachers perceived that the children in the fourth to sixth grades in the Sleman District (suburban) and the city (urban) had excellent communication skills, as expressed in the interviews. "The children can make friends easily, and they respect each other" (T4/urban). "Most students can communicate with their classmates to engage in good teamwork" (T8/suburban). 
However, the teachers said that children in the volcano disaster area did not exhibit good communication skills and should interact with friends (becoming familiar with friends) to reduce their negative behaviors (angry, lazy, mischievous, and irreverent). "The children are less able to control their emotions (high emotion) and concerns about friends" (T2/disaster). "The children in the disaster areas tend to be aggressive when performing activities outside the classroom (such as sports or exercise)" (T3/disaster). "The children in the affected areas still lack manners and appropriate behaviors" (T1/disaster).

The PE and sports teachers saw that the children needed communication skills to develop interactions with friends (familiarity with friends) and to reduce their negative behaviors, such as anger, laziness, mischief, and rude behaviors. "They need to strengthen their interpersonal relationships with their teachers" (T7/suburban). "The abilities and characteristics needing improvement by the children are expressing an opinion, self-esteem, and playing with friends" (T6/suburban). "The relationship between the children and their parents are more important for those in the disaster area to ensure their safety" (T1/disaster).

The PE and sports teachers noted that the children in the urban, suburban, and volcanodisaster areas all showed good social-awareness (e.g., concern of friends, empathy with friends, and empathy with special-needs children). "The children have empathy for their friends and can work well in a variety of activities at school" (T4/urban). "The children also have a desire to work in groups, can choose good friends, and empathize with special-needs children" (T2/disaster). "The children have also been able to socialize with friends and teachers" (T7/suburban).

According to the PE and sports teachers, although the children had good social awareness skills, they still needed to develop them. "They should be developed through cooperation and protecting the group" (T8/suburban). "The children need to increase their ability to protect each other with love, especially when volcano eruptions occur" (T1/disaster).

The PE and sports teachers thought that the fourth-to sixth-graders in the suburban, urban, and disaster areas did not have the problem-solving skills needed to deal with their problems and those of others. "In the process of solving problems, the children still need the help of others, such as teachers or parents" (T6/suburban). "The children in the urban areas respond more quickly and can solve problems in their complex environment" (T5/urban). "The children in the disaster area still do not have the thinking skills needed to solve problems (passive cognitive); thus, they are less responsive to a variety of problems" (T2/disaster).

The teachers also emphasized that the problem-solving skills that need to be developed are discussing/deliberating an issue, quickly making decisions, and conflict resolution. "After a disaster, parents also face difficult issues that affect their children's thinking skills" (T1/disaster). "Their children need to improve their ability to express their opinions and their decision-making skills" (T5/urban). "When interacting with friends, children are often involved in conflict; thus, conflict-resolution skills are needed" (T9/suburban). 
When we ask the teacher about the relationship between PE and sports and psychosocial skills, the teachers explained that PE and sports have become a method of improving children's psychosocial skills. "Yes, I think, there is a relationship, but sometimes it is impossible to see, so it needs proof" (T5/urban). "I would like PE and sports to be one of the methods to improve children's psychosocial skills, for example, giving all children an equal chance to try some new games" (T6/suburban). "I have seen that children are happier with PE and sports; it is unlikely that they will become stressed by sports; instead, sports reduce children's stress, and they become more energetic" (T2/disaster).

The teachers were then asked about the relationship between the teachers, students, and parents regarding the children's psychosocial development. "I felt that we had a close relationship, for example, we were able to discuss their problems with learning and the relationships between students were not a problem" (T3/disaster). "Yes, these relationships exist; the parents always asked teachers to teach psychosocial skills to their children" (T4/urban).

Yes, a good relationship enhances psychosocial skills through actual behaviors, for example, if a friend was sick, students asked to visit the friend, or when a friend's parent became ill or died, the students requested to visit the friend together (T6/suburban).

\section{Students' Negative Emotional State}

Table 6

Statistical summary of negative emotional states in each area

\begin{tabular}{|c|c|c|c|c|c|c|c|c|}
\hline \multirow{2}{*}{$\begin{array}{l}\text { Negative } \\
\text { emotional } \\
\text { states }\end{array}$} & \multicolumn{2}{|c|}{$\begin{array}{l}\text { Urban Area } \\
(\mathrm{N}=186)\end{array}$} & \multicolumn{2}{|c|}{$\begin{array}{l}\text { Suburban Area } \\
(\mathrm{N}=401)\end{array}$} & \multicolumn{2}{|c|}{$\begin{array}{l}\text { Disaster Area } \\
(\mathrm{N}=158)\end{array}$} & \multirow[t]{2}{*}{$\mathrm{F}$} & \multirow[t]{2}{*}{$\mathrm{p}$} \\
\hline & Mean & SD & Mean & SD & Mean & SD & & \\
\hline Depression & 7.32 & 5.702 & 5.72 & 4.669 & 6.04 & 4.689 & $6.735^{*}$ & 0.001 \\
\hline Anxiety & 9.83 & 5.582 & 9.49 & 5.261 & 7.51 & 4.404 & $10.471 *$ & 0.000 \\
\hline Stress & 10.94 & 6.505 & 11.59 & 6.116 & 7.91 & 4.836 & $21.907 *$ & 0.000 \\
\hline
\end{tabular}

Note: $* \mathrm{p}<0.05, \mathrm{SD}=$ Standard Deviation.

There was a significant difference in mean scores in depression $(\mathrm{F}(2,744)=6.735, \mathrm{p}=$ $0.001)$, anxiety $(\mathrm{F}(2,744)=10.471, \mathrm{p}=0.000)$, and stress $(\mathrm{F}(2,744)=21.907, \mathrm{p}=$ 0.000 ) between children in urban, suburban, and disaster area. It is summarized in Table 6. It can be described that there was a significant mean difference on children's depression state between disaster and urban area $(\mathrm{p}=0.017)$ and urban and suburban $(\mathrm{p}$ $=0.000)$, but not between disaster and suburban $(\mathrm{p}=0.489)$. A significant mean difference was observed in children's anxiety state between disaster and urban area $(\mathrm{p}=$ $0.000)$ and disaster and suburban $(\mathrm{p}=0.000)$, but not between urban and suburban $(\mathrm{p}=$ 0.460). In children's stress state, there was a significant mean difference between disaster and urban area $(\mathrm{p}=0.000)$ and disaster and suburban $(\mathrm{p}=0.000)$, but not between urban and suburban $(\mathrm{p}=0.215)$. Table 7 presents the LSD post hoc analysis to show mean differences between areas mentioned above. 
Table 7

Post hoc LSD analysis of negative emotional states

\begin{tabular}{lccl}
\hline \multirow{2}{*}{ Area } & Mean differences & & \\
\cline { 2 - 4 } & Depression & Anxiety & Stress \\
\hline Disaster-urban & $-1.279^{*}$ & $-2.372^{*}$ & $-3.030^{*}$ \\
\hline Disaster-suburban & 0.322 & $-1.987^{*}$ & $-3.688^{*}$ \\
\hline Urban-suburban & $-1.601^{*}$ & -0.340 & -0.658 \\
\hline
\end{tabular}

Note: $* \mathrm{p}<0.05$

The children's depression state in the disaster area was a significantly lower than the urban area $(\mathrm{M}=6.04<\mathrm{M}=7.32)$, but it was not significantly higher than suburban $(\mathrm{M}$ $=6.04>\mathrm{M}=5.72)$. The disaster area was considerably lower than the urban area $(\mathrm{M}=$ $7.51<M=9.83)$ and the suburban area $(M=7.51<M=9.49)$ in relation to children's anxiety state. The children's stress state in the disaster area was significantly lower than the urban area $(M=7.91<M=10.94)$ and the suburban area $(M=7.91<M=11.59)$. Overall, it can be concluded that negative emotional state of children in disaster area was significantly lower than the urban and suburban area.

\section{DISCUSSION}

\section{Students' Psychosocial Skills}

The teachers believed that the children from all three areas had adequate psychosocial skills, but required support to develop skills for coping with stress, communication, social awareness, and problem solving. However, the children living in the disaster area had a lower negative emotional state than those residing in the urban and suburban areas. The students in disaster areas are necessary to enhance the psychosocial skills and keep or reduce their negative emotional states through physical education and sports programs, which involve various activities to have a positive impact on both aspects of children.

The PE and sports teachers perceived that the children did not have good coping skills to deal with stress and needed to develop them. Children require coping skills to survive and continue their lives; thus, they needed to develop appropriate coping skills to promote and maintain their physical and psychological well-being (Wagner, Myers \& McIninch, 1999; Kadhiravan \& Kumar, 2012). Jellesma (2013) stated that coping with stress is complicated and physical symptoms emerge in many children. Mondal et al. (2013) emphasized that in children affected by disaster, the loss of family members, structural devastation, or a fear response can result in emotional deterioration, and stress-related symptoms begin to appear immediately after the disaster. Another perspective is that the coping strategies of children determine their psychological reactions to the disaster that facilitate coping and rapid recovery, ensuring positive outcomes that are sustained (Kar, 2009).

The PE and sports teachers noticed that the children in the suburban and urban areas had good communication skills, but those in the disaster area did not exhibit this strength; therefore, children in all areas still need to develop communication skills. Communication skills are considered amongst the most essential skills required by children in disaster areas. The necessary skills were seen as urgent because 
communication is a basic skill learned in personal and social frameworks (Hollander, Wood, \& Herbert, 2003). Moreover, communication is the process of mutually transferring feelings and thoughts (Aydin, 2015). It matters how a person expresses him/herself through interactions with others (Erdogan \& Bayraktar, 2014).

The PE and sports teachers believed that the children had social awareness skills, but needed to develop them. Social awareness is the ability to take the perspective of and empathize with others from diverse backgrounds and cultures, to understand the social and ethical norms for behavior, and to recognize family, school, and community resources and support (Collaborative for Academic, Social, Emotional Learning, 2015). The term empathy refers to two related human abilities: mental perspective taking (cognitive empathy) and the vicarious sharing of emotion (emotional empathy) (Smith, 2006; Cotton, 2001). Children who have social awareness can think critically and adapt to social changes (Tsui, 2000; Greene \& Kamimura, 2003).

The PE and sports teachers felt that the children in all of the areas in this study lacked problem-solving skills and needed to improve them. Learning problem-solving skills is important for every aspect of a child's life, both personal and social aspects (Gorucu, 2016). Children with well-developed problem-solving skills can identify effective solutions to a problem (Thompson, Bhatt, \& Watson, 2013). Educational programs must be based on problems that students are most likely to face during their lives, and education should be imparted through activities that support them (Tasgin, 2011; Yigiter, 2013).

Both individual teachers and schools have devoted much effort to developing psychosocial skills. Routine psychosocial activities in the school setting, the provision of instructional materials, and incidentals activities are examples of such efforts. During the school's psychosocial activities, the children participated in joint activities, such as a homestay program, scouting, ceremonies, field trips, praying, morning exercise, being in line before entering the classroom, and playing through dancing and singing. These activities are consistent with those of Jenkinson and Benson (2010), who identified schools as appropriate settings to promote health and physical activity because of the amount of time students spend there and because the curricula are sufficiently adaptable to include such content. For the instructional activities, teachers integrated psychosocial skills into their lessons. These activities included practicing the expression of opinions, discussing seating arrangements in the classroom, emphasizing materials to teach volcanic or disaster knowledge, and deciding on the types of games and sports used in physical education. These activities were designed in accordance with the essential role of the teacher to help students learn and apply the moral reasoning process and to serve as role models for telling the truth, respecting others, accepting and fulfilling responsibility, playing fair, earning and returning trust, and living a moral life (Lumpkin, 2008). The potential for teachers to support or thwart students' innate psychological needs for autonomy, competence, and relatedness were explored (Taylor, Ntoumanis, \& Smith, 2009). Incidental activities, such as participation in voluntary events, social activities, non-government organizations (NGO) training programs, and the Disaster Management Institution or related agency programs were also available to students. 
The teachers mentioned that PE and sports are a positive way to improve children's psychosocial skills by giving them opportunities, such as trying new games, participation in multicultural groupings, socialization, cooperation, and enjoying movement. PE is an important educational contributor to students' personal development and provides opportunities for enjoyment, learning new motor skills, and cooperating with others (Hassandra, Goudas, \& Chroni, 2003). The PE teachers can help students to develop important character and moral virtues (Lumpkin, 2008). Therefore, establishing healthy relationships amongst teachers, students, and parents should lead to students' positive behaviors and psychosocial skills development.

\section{Students' Negative Emotional States}

The current study found that the negative emotional state of the children in the disaster area was significantly lower than that of the children in the urban and suburban areas. This finding is inconsistent with the researcher's initial assumption that the negative emotional state of the children in the disaster area would be higher than that of the children in the urban and suburban areas, as reported by Aslam and Tariq (2010). Their previous study found that individuals living in areas affected by disasters scored significantly higher on measures of depression, anxiety, and stress compared to those living in unaffected areas. There are several possible explanations for finding a lower negative emotional state among the children in the disaster area. For example, religious (Lavigne et al., 2008) and cultural (Jogia, Kulatunga, Yates, \& Wedawatta, 2014) factors affecting children's encounters with and responses to natural disasters should be examined.

The children who were affected by the disaster had returned to their pre-crisis level of psychological functioning. As it was with the one year after the earthquake case, fear and anxiety symptoms tended to diminish (Uemoto et al., 2012). Moreover, the psychosocial rehabilitation programs by the government and non-government organizations after the disaster might have affected the children's negative emotional state. Psychosocial rehabilitation intervention is necessary for individuals who are victims of a disaster (Aslam \& Tariq, 2010; Kolaitis, 2011; Kar, 2009; Uemoto et al., 2012). Furthermore, the complexity of the lives of the children who lived in the urban and suburban areas might have contributed to their higher negative emotional state than children who lived in the disaster area.

\section{CONCLUSIONS}

The PE and sports teachers perceived that the children in the fourth to sixth grades had good psychosocial skills, but required some improvements in their skills for coping with stress, communication, social awareness, and problem-solving. They also thought that PE and sports could be an effective way for primary schools to develop children's psychosocial skills. The teachers also recognized that healthy relationships amongst the teachers, students, and parents were important factors in the success of the teachers' efforts to help children develop psychosocial skills. The children who lived in the disaster area had a lower negative emotional state than those who lived in the urban and suburban areas. Further investigations of the impact of the PE and sports program should involve a variety of activities to decrease children's negative emotional state, and, more importantly, to develop their psychosocial skills. 


\section{ACKNOWLEDGEMENTS}

We would like to thankful to PE teachers and students who were involved in the study. This work supported by KAKENHI under grant (number JP24500704 \& JP16K12980).

\section{REFERENCES}

Al-Rawahi, N., \& Al-Yarabi, A. (2013). The Relationship between Attitudes toward Participation in Physical Activities and Motives for Choosing Teaching Physical Education as a Career. International Journal of Instruction, 6(2), 177-192.

Aslam, N., \& Tariq, N. (2010). Trauma, depression, anxiety, and stress among individuals living in earthquake affected and unaffected areas. Pakistan Journal of Psychological Research, 25, 131-148.

Aydin, A. D. (2015). Assessment of communication skills of physical education and sport students in Turkish universities. Universal Journal of Educational Research, 3(11), 943-948. doi:10.13189/ujer.2015.031125

Chung, D. (2018). The Eight Stages of Psychosocial Protective Development: Developmental Psychology. Journal of Behavioral and Brain Science, 8, 369-398. doi: 10.4236/jbbs.2018.86024

Collaborative for Academic, Social, Emotional Learning (CASEL). (2015). Social and Emotional Learning Core Competencies. Chicago, IL: Author. Retrieved from http://www.casel.org/social-and-emotional-learning/core-competencies

Cotton, K. (2001). Developing empathy in children and youth. School Improvement Research Series Close Up \# 13. Retrieved from http://www.nwre1.org/scpd/sirs/7/cu13.html

Erdogan, T., \& Bayraktar, G. (2014). Effects of sports on communication skills: A research on teacher candidates. Research on Humanities and Social Sciences, 4(2), 68-74.

Fan, D-f. (2015). The Research of the Relationship between Teachers and Students in the New Mode of Physical Education. The Open Cybernetics \& Systemics Journal, 9, 3031-3035.

Finn, K. E. and McInnis, K. J. (2014). Teachers' and Students' Perceptions of the Active Science Curriculum: Incorporating Physical Activity into Middle School Science Classrooms. The Physical Educator, 71(2), 234-253.

Görgüt, I \& Tutkun, E. (2018). Views of Physical Education Teachers on Values Education. Universal Journal of Educational Research, 6(2), 317-332. doi: 10.13189/ujer.2018.060215

Gorucu, A. (2016). The investigation of the effects of physical education lessons planned in accordance with cooperative learning approach on secondary school students' problem solving skills. Educational Research and Reviews, 11(10), 998-1007. doi:10.5897/ERR2016.2756

Government of Yogyakarta Special Region. (2010, June 1). Pemerintah Daerah Istimewa Yogyakarta. Retrieved August 19, 2015 from http:/www.pemda-diy.go.id/ 
Greene, S. R., \& Kamimura, M. (2003). Ties that Bind: Enhanced Social Awareness Development through Interactions with Diverse Peers. The annual meeting of the association for study of higher education Portland. Oregon.

Hassandra, M., Goudas, M., \& Chroni, S. (2003). Examining Factors Associated with Intrinsic Motivation in Physical Education: A Qualitative Approach. Psychology of Sport and Exercise, 4, 211-223.

Hollander, D. B., Wood, R. J., \& Herbert, E. P. (2003). Protecting students against substance abuse behaviors: Integrating personal and social skills into physical education. Journal of Physical Education, Recreation, \& Dance, 74(5), 45-48. doi:10.1080/07303084.2003.10608485

Jellesma, F. C. (2013). Stress and yoga in children. Journal of Yoga and Physical Therapy, 3, 1-3. doi:10.4172/2157-7595.1000136

Jenkinson, K. A., \& Benson, A. C. (2010). Barriers to Providing Physical Education and Physical Activity in Victorian State Secondary Schools. Australian Journal of Teacher Education, 35(8), 1-17.

Jogia, J., Kulatunga, U., Yates, G. P., \& Wedawatta, G. (2014). Culture and the psychological impacts of natural disasters: implications for disaster management and disaster mental health. The Built \& Human Environment Review, 7, 1-10.

Kadhiravan, S. \& Kumar, K. (2012). Enhancing stress coping skills among college students. Journal of Arts, Science \& Commerce, 4(1), 49-55.

Kar, N. (2009). Psychological impact of disaster on children: Review of assessment and interventions. World Journal of Pediatric, 5, 5-11. doi:10.1007/s12519-009-0001-x

Kilic, E. Z., Ozguven, H. D., \& Sayil, I. (2003). The Psychological effects of parental mental health on children experiencing disaster: The experience of Bolu earthquake in Turkey. Family Process, 42, 485-495. doi:10.1111/j.1545-5300.2003.00485.x

Kolaitis, G., Giannakopoulos, G., Mihas, C., Ntre, V., Moulla, V., Sotiropoulou, E., Paflia, K., Assimopoulos, H., Argyrou, K., Tsiantis, J., Kotsirilou, K., Tomaras, V., Leventakou, V., \& Tzavara, C. (2011). Symptoms of posttraumatic stress, depression, and anxiety among youths exposed to a massive fire disaster in Greece. British Journal of Medicine \& Medical Research, 1, 320-332. doi:10.9734/BJMMR/2011/505

Lavigne, F., De Coster, B., Juvin, N., Flohic, F., Gaillard, J.-C., Texier, P., et al. (2008). People's behavior in the face of volcanic hazards: perspectives from Javanese communities, Indonesia. Journal of Volcanology and Geothermal Research, 172, 273 287. doi:10.1016/j.jvolgeores.2007.12.013

Lovibond, S. H., \& Lovibond, P. F. (1995). Manual for the depression anxiety stress scales second edition. Sydney: Psychology Foundation.

Lumpkin, A. (2008). Teachers as role models teaching character and moral virtues. Journal of Physical Education, Recreation, \& Dance, 79(2), 45-49.

Miles, M. B \& Huberman, A. M. (1984). Qualitative data analysis. Beverly Hills, California: Sage Publication. 
Mondal, R., Sarkar, S., Banerjee, I., Hazra, A., Majumber, D., Sabui, T., Dutta, S., Saren, A., \& Pan, P. (2013). Acute stress-related psychological impact in children following devastating natural disaster, the Sikkim earthquake (2011) India. Journal of Neurosciences in Rural Practice, 4, 19-23. doi:10.4103/0976-3147.116434

Ronholt, S., Karsberg, S., \& Elklit, A. (2013). Preliminary evidence for a classroom based psychosocial intervention for disaster exposed children with posttraumatic stress symptomatology. Child Youth Care Forum, 42, 617-631. doi:10.1007/s10566-013-9220-3

Sagala, S., Rosyidie, A., Pratama, A., Wimbardana, R. and Wijayanti, A. (2012). Promoting Volcano Tourism in Hazard Zone Area for Rebuilding Local Economy: Case study of Tourism in Cangkringan Sub-District, Mt. Merapi, Yogyakarta. Research Report. Bandung: Program Studi Perencanaan Wilayah dan Kota SAPPK, Institut Teknologi Bandung.

Smith, A. (2006). Cognitive empathy and emotional empathy in human behavior and evolution. The Psychological Record, 56, 3-12

Tasgin, Ö. (2011). Examining problem-solving skills of physical education and sport students from several factors. Collegium Antropologicum, 2, 325-328.

Taylor, I. M., Ntoumanis, N., \& Smith, B. (2009). The social contact as a determinant of teacher motivational strategies in physical education. Psychology of Sport and Exercise, 10(2009), 235-243.

Thompson, D., Bhatt, R., \& Watson, K. (2013). Physical activity problem-solving inventory for adolescents: development and initial validation. Pediatric Exercise Science, 25, 448-467. doi:10.1123/pes.25.3.448

Tsui, L. (2000). Effects of campus culture on students' critical thinking. The Review of Higher Education, 23 (4), 421-441. doi:10.1353/rhe.2000.0020

Tutkun, E., Görgüt, I., \& Erdemir, I. (2017). Physical Education Teachers' Views about Character Education. International Education Studies, 10(11), 86-99. doi: $10.5539 /$ ies.v10n11p 86

Uemoto, M., Asakawa, A., Takamiya, S., Asakawa, K., \& Inui, A. (2012). Kobe earthquake and post-traumatic stress in school-aged children. International Journal of Behavior and Medicine, 19, 243-251. doi:10.1007/s12529-011-9184-3

Wagner, E.F., Myers, M.G., \& McIninch, J.L. (1999) Stress-coping and temptationcoping as predictors of adolescent substance use. Addictive Behaviors, 24(6), 769-779. doi:10.1016/S0306-4603(99)00058-1

Wolmer, L., Laor, N., Dedeoglu, C., Siev, J., \& Yazgan, Y. (2005). Teacher-mediated intervention after disaster: a controlled three-year follow-up of children's functioning. Journal of Child Psychology and Psychiatry, 46(11), 1161-1168.

Yonekura, T., Ueno, S., \& Iwanaka, T. (2013). Care of children in a natural disaster: Lesson learned from the great East Japan earthquake and tsunami. Pediatric Surgery International, 29, 1047-1051. doi:10.1007/s00383-013-3405-6 